\title{
The belemnite zonation of the uppermost Cretaceous in the Maastricht-Aachen-Liège, Brabant-Méhaigne and Mons areas (Belgium, southeast Netherlands)*
}

\section{N. Keutgen}

KFPBR, Uniwersytet Techniczno-Przyrodniczy Bydgoszcz, ul. Bernardynska 6/8, PL-85 029 Bydgoszcz, Poland. Email: keutgen@utp.edu.pl.

Manuscript received: January 2011, accepted: July 2011

\begin{abstract}
An overview is presented of belemnitellid faunas of Santonian to Maastrichtian (Late Cretaceous) age in the Mons Basin and in the Brabant-Méhaigne and Maastricht-Aachen-Liège areas (Belgium, southeast Netherlands). As many as twenty-two species of the genera Actinocamax Miller, 1823, Gonioteuthis Bayle, 1878, Belemnitella d'Orbigny, 1840 and Belemnella Nowak, 1913 have been recorded to date. On the basis of these, thirteen zones can be distinguished: three in the Santonian (G. w. westfalica, G. westfalicagranulata and G. granulata), six in the Campanian (G. granulataquadrata, G. quadrata, Blt. mucronata, Blt. woodi, Blt. minor I and Blt. minor II) and four in the Maastrichtian (Bln. obtusa, Bln. ex gr. sumensis/cimbrica, Blt. junior and Bln. kazimiroviensis). Correlative schemes between these zones and those proposed for Norfolk (southeast England) and for the combined Lägerdorf-Kronsmoor-Hemmoor section (northern Germany) are presented. The belemnitellid assemblage of the study area closely resembles that of Norfolk, but differs from the late Campanian faunas of northwest Germany.
\end{abstract}

Keywords: Belemnitellids, stratigraphy, Actinocamax, Gonioteuthis, Belemnitella, Belemnella, Upper Cretaceous, Belgium, the Netherlands

\section{Introduction}

During the last decades, belemnitellid cephalopods (Coleoidea) have been considered to be of fundamental importance for biostratigraphy and correlation of the Upper Cretaceous of Europe, particularly during the Santonian to Maastrichtian stages, because they are common and widely distributed and have a high fossilisation potential (Christensen, 1996, 1997). However, detailed studies carried out by Christensen (1995, 1999, 2000a, b) have shown a significant regional component within distributional patterns, in particular for the genus Belemnitella, during the late Campanian in northwest Europe. While in Norfolk (southeast England), the Maastricht-AachenLiège area (MAL; southeast Netherlands and adjacent areas) and the Mons Basin (southern Belgium), members of the lineage Blt. mucronata / woodi / minor I/ minor II predominate, Blt. mucronata persisted in northern Germany (Misburg-Höver area, east of Hannover) and Skåne, southern Sweden, (almost) to the top of the Blt. woodi Zone in the lower upper Campanian. In the upper upper Campanian, members of the Blt. minor group have not (yet) been identified in northern Germany (Kronsmoor, Lägerdorf), but there Blt. langei (sensu Schulz, 1978) and Blt. schulzi appear, two forms apparently restricted to that region and unknown from Norfolk, the Mons Basin and the MAL area. From the Vistula (Wisła) River valley in east-central Poland, another rich Belemnitella fauna has recently been noted in the upper Campanian, comprising additional regional elements such as Blt. posterior Kongiel, 1962 (Christensen, unpubl. data; Remin, 2007).

According to Christensen (2000b), his earlier suggestion (see Christensen, 1999) that the upper Campanian belemnite zonation of Norfolk could be used as a formal zonation throughout northwest Europe was no longer tenable. Hence, it is necessary first to establish regional belemnite zonations based on developmental lineages of the locally dominant species and, secondly, to note temporary invasions of additional species. These short-term invasions may be of great stratigraphic value as has been documented for instance for Bln. praearkhangelskii in the upper lower Maastrichtian of northwest Europe (Schulz, 1979; Keutgen, 1997). Alternatively, such temporary immigration events may reflect temporarily suitable environmental

* In: Jagt, J.W.M., Jagt-Yazykova, E.A. \& Schins, W.J.H. (eds): A tribute to the late Felder brothers - pioneers of Limburg geology and prehistoric archaeology. 
conditions for these belemnite species, which should then be considered more or less stenoecious.

The Upper Cretaceous deposits in the MAL, Brabant-Méhaigne and Mons areas (Fig. 1) have been subdivided into a large number of lithostratigraphic units; lithologies comprise chalks, calcarenites, calcirutites, sandstones, sands, silts and clays (Robaszynski et al., 2002). Differences in facies, and hence faunas, have hampered correlation of lithostratigraphic units. For example, the Benzenrade Member, considered the uppermost unit of the Vaals Formation, replaces (almost) the entire Gulpen Formation in the block-faulted region close to the Rur Valley Graben in the MAL area (Jagt, 1999; W.M. Felder \& Bosch, 2000).

In addition, the exact stratigraphic age of the base and top of certain lithostratigraphic units is not well documented; in fact, it may even differ among localities. An example is the Vijlen Member, the oldest portions of which have been preserved solely within channel-like structures (P.J. Felder, 1997). Facies relationships in the MAL area have been discussed more fully by Bless et al. (1987) and P.J. Felder (2001), to whom reference is made.

The present study summarises available data on belemnitellid distribution during the Santonian, Campanian and Maastrichtian in the study area. None of these classic areas (separated by $125 \mathrm{~km}$ at most) offers a complete belemnite record for the latest 20 myr of the Cretaceous, but taken together, these regions provide an adequate overview of belemnite taxa populating these nearshore habitats, which were under tectonic control by the Ardennes and Brabant-London massifs and the Roer Valley Graben in the north.

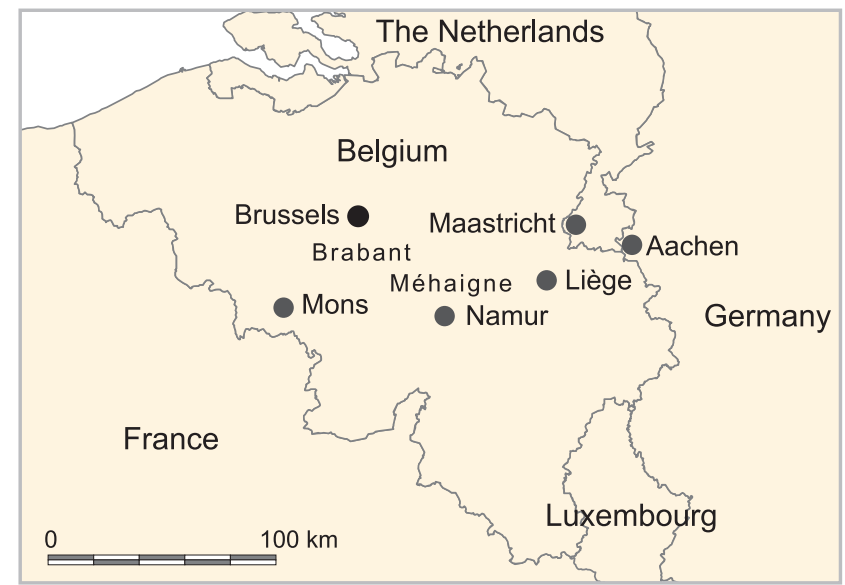

Fig. 1. Map showing the location of the Mons Basin and the BrabantMéhaigne and Maastricht-Aachen-Liège (MAL) areas.

\section{Santonian-Maastrichtian belemnite zones; belemnites and stage boundaries}

\section{Coniacian/Santonian boundary}

This boundary is defined by the first appearance datum (FAD) of the inoceramid bivalve Cladoceramus undulatoplicatus (Roemer, 1852), as discussed by Gale et al. (2007). The Santonian Stage is subdivided into a lower, middle and upper portion, but boundaries between these cannot be identified by belemnites. Gonioteuthis westfalica praewestfalica Ernst \& Schulz, 1974 crosses the Coniacian/Santonian boundary, while G. w. westfalica (Schlüter, 1876) is known from the upper lower and lower middle Santonian (Christensen, 1997). Only the base of the upper Santonian can be identified by the FAD of Gonioteuthis granulata (De Blainville, 1827).

\section{Santonian belemnite zones}

Gonioteuthis westfalica westfalica Zone

Age

Late early-early middle Santonian.

\section{Species recorded}

Gonioteuthis w. westfalica and Actinocamax verus Miller, 1823.

\section{Example}

Lonzée Member ('Glauconie de Lonzée') near Gembloux, southeast Belgium.

\section{Reference}

Christensen (1994).

\section{Remarks}

Belemnitellids from the Lonzée Member represent a heterogeneous lot, comprising different species of Gonioteuthis. The majority of specimens can be assigned to G. w. westfalica and hence most belemnites in this unit, including $A$. verus, are assumed to originate from this zone. The Lonzée Member either represents a condensed deposit, with repeated winnowing having resulted in an admixture of belemnites from different zones, or, alternatively, is of late Santonian age (possibly even younger, i.e., earliest Campanian), and contains species reworked from the lower and middle Santonian. In Fig. 2, the first interpretation is favoured, in line with Robaszynski et al. (2002, fig. 1). The Lonzée Member in the Brabant-Méhaigne area is generally considered to be coeval with the Saint-Vaast Chalk Formation in the Mons Basin, for which Robaszynski et al. (2002) recorded A. verus. In England, this species ranges from the Coniacian to the lower lower Campanian Offaster pilula Zone sensu germanico (Christensen, 1991).

\section{Gonioteuthis westfalicagranulata Zone}

\section{Age}

Late middle Santonian.

\section{Species recorded}

Gonioteuthis westfalicagranulata (Schlüter, 1876) and Actinocamax verus(?). 


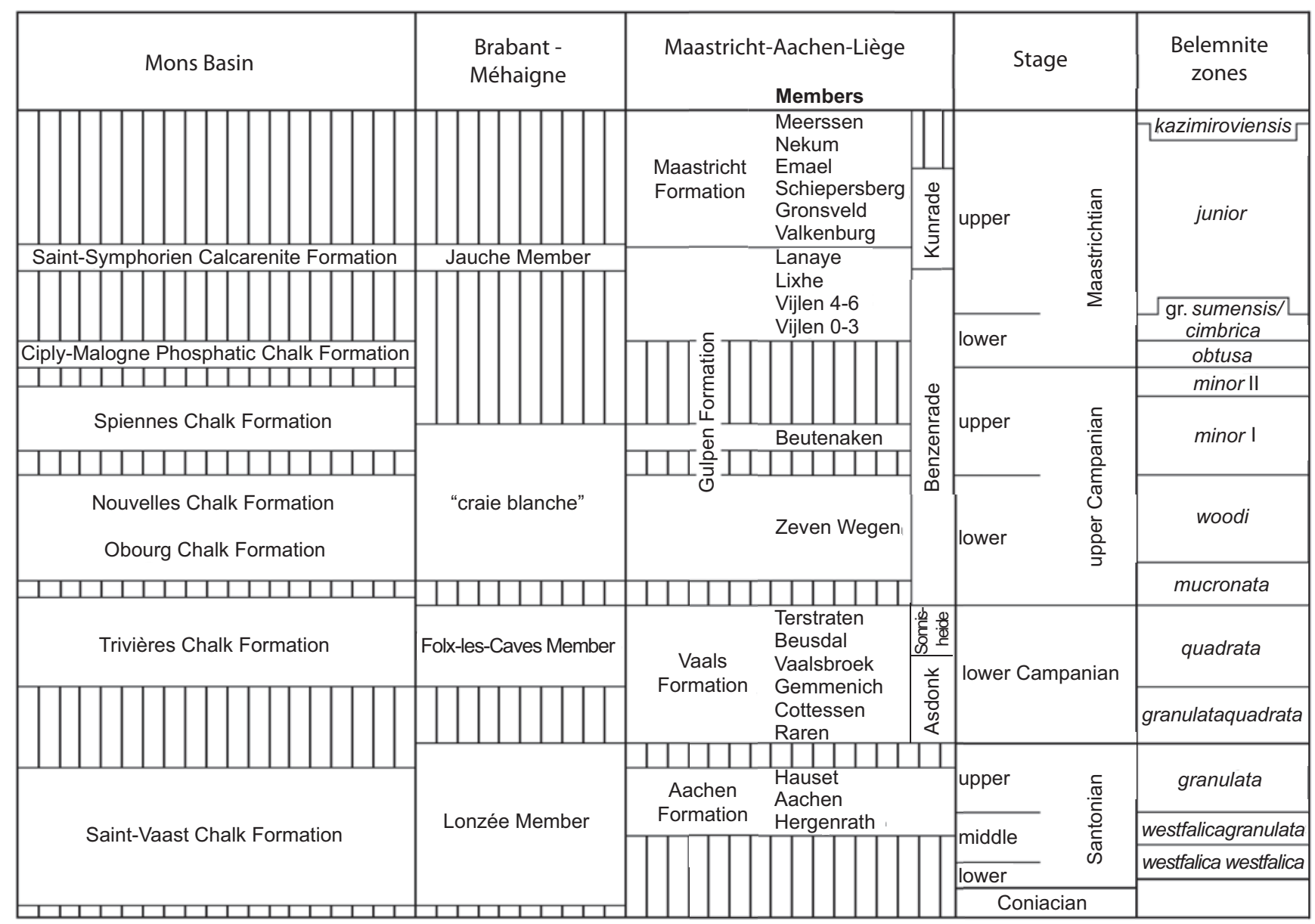

Fig. 2. Stratigraphic age and belemnite zones for the Upper Cretaceous (Santonian-Maastrichtian) of the Mons Basin and the Brabant-Méhaigne and Maastricht-Aachen-Liège areas.

\section{Examples}

Vaals Formation (Asdonk Member) in the Campine Basin, northeast Belgium; material collected during mine shaft construction (Houthalen and Zolder/Voort collieries); Lonzée Member near Gembloux, southeast Belgium.

\section{References}

Christensen (1994) and Jagt et al. (1995b).

\section{Remarks}

A small sample of Gonioteuthis from the Houthalen and Zolder/Voort collieries (MAL area) has been assigned to $G$. westfalicagranulata by Jagt et al. (1995b). In addition, a few specimens from Lonzée have been referred here (Christensen, 1994). In view of the fact that $A$. verus is unknown from the former Houthalen and Zolder/Voort collieries, but does occur at Lonzée, its presence in this zone cannot be ascertained (Fig. 3).

Slimani et al. (2011) proposed an early Campanian date for the levels penetrated in the Houthalen and Zolder/Voort mine shafts, which is at odds with the late middle Santonian date based on belemnites. Nannofossil assemblages indicate a late Santonian, possibly early Campanian, age (Jagt et al., 1995b), similar to what Slimani et al. (2011) suggest. Should future studies document an earliest Campanian date for these deposits, G. westfalicagranulata from the Houthalen and Zolder/Voort collieries may be considered to have been reworked.

Data from geophysical well logs, cores and boreholes in the Campine Basin favour a twofold subdivision of the Vaals Formation into an upper (Sonnisheide Member) and a lower (Asdonk Member) unit. The relationships to the classic six members of the Vaals Formation in the Aachen-Vaals area have not been firmly established yet. The base of the Sonnisheide Member corresponds to the base of Ecozone Ic of P.J. Felder (2001), which was tentatively correlated with the base of the Beusdal Member in the type area of the Vaals Formation (P.J. Felder, 2001).

Gonioteuthis granulata Zone

\section{Age}

Late Santonian.

\section{Species recorded}

Gonioteuthis granulata (De Blainville, 1827) and Actinocamax verus(?). 


\section{Example}

Lonzée Member near Gembloux, southeast Belgium.

\section{Reference}

Christensen (1994).

\section{Remarks}

Christensen (1994) assigned some guards from this unit to $G$. granulata.

\section{Santonian/Campanian boundary}

This boundary equates with the last appearance datum (LAD) of the crinoid Marsupites testudinarius (Von Schlotheim, 1820), as discussed by Gale et al. (2008), which coincides with the FAD of Gonioteuthis granulataquadrata (Stolley, 1897) in northwest Germany (Gale et al., 1995). The lower Campanian substage may be subdivided into a lower and an upper portion, the boundary being situated within the Gonioteuthis q. quadrata Zone (Fig. 3).

\section{Lower Campanian belemnite zones}

\section{Gonioteuthis granulataquadrata Zone}

\section{Age}

Earliest early Campanian.

\section{Species recorded}

Gonioteuthis granulataquadrata and Belemnitella praecursor Stolley, 1897.

\section{Examples}

Vaals Formation, uppermost Cottessen and Gemmenich members (c. $0.3 \mathrm{~m}$ below and c. $6.1 \mathrm{~m}$ above the Gemmenich Horizon) at Aachen-Lütticher Straße, 0sterweg (western Germany).

\section{Reference}

Albers (1976).

\section{Remarks}

The identification of $G$. granulataquadrata near Aachen was based on five plus eight specimens (Albers, 1976), respectively, which may be regarded the critical number of specimens needed for a reliable assessment. One of the specimens from the Gemmenich Member had a deep pseudoalveolus and thus resembled G. quadrata (De Blainville, 1827). For this reason, the top of the G. granulataquadrata Zone is placed tentatively within the Gemmenich Member (Fig. 2).

A fragment of Blt. praecursor is known from the uppermost Cottessen Member (Albers, 1976). From the Lonzée Member, Christensen (1994) noted two specimens of Gonioteuthis with a comparatively deep pseudoalveolus; these represent either G. granulata or G. granulataquadrata.

\begin{tabular}{|c|c|c|c|c|}
\hline & & $\begin{array}{l}\text { Biozones of Läger- } \\
\text { dorf }\end{array}$ & $\begin{array}{l}\text { Belemnite zones of Läger- } \\
\text { dorf (northern Germany) } \\
\text { and England }\end{array}$ & $\begin{array}{l}\text { Belemnite zones of Mons } \\
\text { basin and Maastricht- } \\
\text { Aachen-Liège area }\end{array}$ \\
\hline \multirow{8}{*}{ 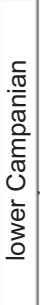 } & \multirow{5}{*}{$\begin{array}{l}\frac{1}{0} \\
\frac{0}{3}\end{array}$} & gracilis/mucronata & G. q. gracilis/Blt. mucronata & \multirow{7}{*}{ G. quadrata } \\
\hline & & conica/gracilis & G. quadrata gracilis & \\
\hline & & papillosa & \multirow{5}{*}{ G. quadrata quadrata } & \\
\hline & & senonensis & & \\
\hline & & pilula/senonensis & & \\
\hline & & pilula & & \\
\hline & $\sum_{0}^{\infty}$ & lingua/quadrata & & \\
\hline & 으 & granulataquadrata & G. granulataquadrata & G. granulataquadrata \\
\hline \multirow{6}{*}{ 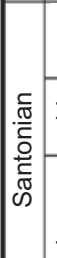 } & $\overline{\grave{\omega}}$ & Marsupites/granulata & \multirow{2}{*}{ G. granulata } & \multirow{2}{*}{ G. granulata } \\
\hline & $\frac{2}{3}$ & Uintacrinus/granulata & & \\
\hline & ن & rogalae/westfalicagranulata & G. westfalicagranulata & G. westfalicagranulata \\
\hline & $\bar{\varepsilon}$ & rogalae/westfalica & \multirow{2}{*}{ G. westfalica westfalica } & \multirow{2}{*}{ G. westfalica westfalica } \\
\hline & & coranguinum/westfalica & & \\
\hline & 递 & pachti/undulatoplicatus & G. westfalica praewestfalica & $\begin{array}{l}\text { Gonioteuthis extremely } \\
\text { rare in NW Europe }\end{array}$ \\
\hline
\end{tabular}

Fig. 3. Stratigraphical correlation diagram for the Santonian and lower Campanian (sources: Schulz et al., 1984; Christensen, 1997; Niebuhr, 2006). Abbreviations: $A .=$ Actinocamax, $B l t .=$ Belemnitella, $G .=$ Gonioteuthis. Dots indicate that the presence of a species at this level is uncertain. Vertical axis not to scale.

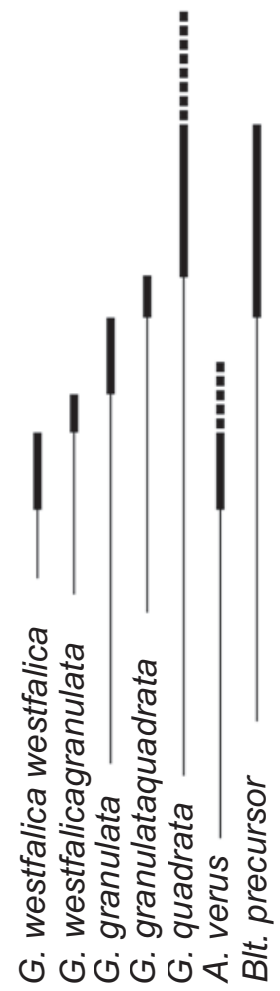


Gonioteuthis quadrata Zone

\section{Age}

Youngest portion of early early and late early Campanian.

\section{Species recorded}

Gonioteuthis quadrata and Belemnitella praecursor.

\section{Examples}

Vaals Formation, lowermost Beusdal Member, Hombourg, northeast Belgium; Vaals Formation, uppermost $3 \mathrm{~m}$ of smectite facies, former Ciments Portland Liégeois (CPL SA) quarry, Haccourt, northeast Belgium; Folx-les-Caves Member, Folx-les-Caves, Jauche (Orp-Jauche, eastern Brabant, Belgium).

\section{References}

Albers (1976), Christensen \& Schmid (1987), Bless et al. (1991).

\section{Remarks}

According to Christensen \& Schmid (1987), the belemnite assemblage of the uppermost portion of the smectite facies at Haccourt is typical of the upper lingua/quadrata Zone sensu germanico. A comparable age assignment (lingua/quadrata to senonensis zones) was proposed by Albers (1976) for a sample of $G$. quadrata from the Beusdal Member.

Robaszynski et al. (2002) noted G. quadrata from the Trivières Chalk Formation in the Mons Basin and from the Folx-les-Caves Member in the Brabant-Méhaigne region (Petite Gette valley). According to Christensen (1999), Blt. praecursor may occur in the Trivières Chalk Formation as well, but this is in need of confirmation.

Of G. quadrata three subspecies are distinguished, viz. G. q. quadrata, G. q. gracilis (Stolley, 1892) and G. q. scaniensis Christensen, 1975, the last-named representing a geographic subspecies from the uppermost lower Campanian of Skåne, southern Sweden. In the study area, only G. q. quadrata has been identified to date. For comparison, G. q. gracilis has also been recorded from Norfolk (Attlebridge and Ringland), but both specimens known were referred by Christensen (1991) to this subspecies with a query. Fletcher \& Wood $(1978$, p. 95) noted G. q. gracilis from northern Ireland. For the time being, the latest early Campanian G. q. gracilis is not known from the MAL and Mons areas, which is why a G. q. gracilis subzone cannot be distinguished there.

\section{Lower/upper Campanian boundary}

The position of this boundary still is a matter of debate. The 'classic' zonation of the Campanian in the type area of Aquitaine (France) distinguishes, from base to top, a lower Campanian Placenticeras bidorsatum Zone overlain by the Menabites delawarensis Zone, and an upper Campanian Hoplitoplacenticeras marroti Zone, followed by the Bostrychoceras polyplocum Zone.
In the MAL area, the base of the upper Campanian has therefore been placed at the FAD of Hoplitoplacenticeras ( $H$.) marroti (Coquand, 1859) within the upper part of the Vaals Formation (Kennedy, 1986, 1987; Jagt et al., 1995a; Jagt, 1999). From an outcrop near Cottessen (Nieuwe Weg at the Zeven Wegen, between Epen and Vaals, southern Limburg, the Netherlands), Jagt et al. (1995a) recorded three specimens of $H$. marroti, in addition to five specimens from a field south of the so-called 'Koning van Spanje' near Gulpen, all from the Vaals Formation. At Cottessen, all belemnites collected from this formation are referred to as Gonioteuthis gr. quadrata, implying the co-occurrence of a late Campanian index ammonite and an early Campanian index belemnite species. This observation would be in line with the record by Kaever \& Lommerzheim (1991) from the Münsterland area (northwest Germany), where G. quadrata gracilis was found c. $19 \mathrm{~m}$ above the FAD of $H$. marroti, indicating that this ammonite indeed predates the belemnite-defined lower/upper Campanian boundary.

In terms of belemnites, the lower/upper Campanian boundary has commonly been placed at the extinction level of Gonioteuthis (Jeletzky, 1958). The FAD of Belemnitella mucronata (Von Schlotheim, 1813) also predates the demise of Gonioteuthis. In northern Germany, G. quadrata gracilis and Blt. mucronata co-occur within the gracilis/mucronata Zone (Christensen, 2000b). Co-occurrences of Gonioteuthis and Blt. mucronata are also known from the Trivières Chalk Formation in the Mons Basin, c. $0.4 \mathrm{~m}$ below the Obourg Chalk Formation (CCC pit, Harmignies) as well as from the lowermost Zeven Wegen Member (former CPL SA quarry), but the Gonioteuthis material has been considered remanié (Jagt, 1984; Robaszynski \& Christensen, 1989).

In summary, for the MAL, Brabant-Méhaigne and Mons areas, the LAD of G. q. gracilis cannot be used to define the top of the lower Campanian, because this subspecies has not yet been identified. Possible alternative candidates, i.e., the FADs of $H$. marroti or Blt. mucronata, predate the lower/upper Campanian boundary as defined in northwest Germany. The advantage of adopting $H$. marroti as the index taxon is its presence and use as a zonal index in the Aquitaine Basin of southwest France, in addition to its wide distribution with records from Germany, Portugal, Israel, central Asia, Madagascar and Texas (Jagt et al., 1995a). In contrast, Blt. mucronata is less widely distributed, being limited to the North European Province, but occurs more frequently in the corresponding deposits than does $H$. marroti. In the MAL area, it might occur slightly later than $H$. marroti, indicating that its FAD could be closer to the LAD of G. q. gracilis, which defines the lower/upper Campanian boundary in northwest Germany.

It is concluded here that for international correlation the FAD of $H$. marroti is more suitable to define the base of the upper Campanian substage in the study area. Nevertheless, the FAD of Blt. mucronata is accepted for the present study in order to facilitate correlation between the various ints in the study area. 


\section{Lower upper Campanian belemnite zones}

Belemnitella mucronata Zone

\section{Age}

Earliest late Campanian.

\section{Species recorded}

Belemnitella mucronata.

\section{Examples}

Vaals Formation, Benzenrade Member, de Dael (Ubachsberg), the Netherlands; Gulpen Formation, lowermost $5 \mathrm{~m}$ of Zeven Wegen Member, former CPL SA quarry, Haccourt, Belgium; Trivières Chalk Formation (uppermost $6 \mathrm{~m}$ ), CCC pit, Harmignies, Belgium; Obourg Chalk Formation (lowermost $1.2 \mathrm{~m}$ ), CCC pit, Harmignies, Belgium; 'conglomerate' at Folx-les-Caves, Jauche (Orp-Jauche, eastern Brabant, Belgium).

\section{References}

Jagt et al. (1987), Bless et al. (1991), Christensen (1999) and Keutgen \& Jagt (1999).

\section{Remarks}

Belemnitella mucronata persisted in Lower Saxony (northern Germany) and in southern Sweden until the middle late Campanian (Christensen, 1986, 1993, 2000b), whereas it developed towards Blt. woodi Christensen, 1995 in southeast England, Belgium and the Netherlands during the early late Campanian (Christensen, 1995, 1999; Keutgen \& Jagt, 1999).
Belemnitella woodi Zone

\section{Age}

Early late Campanian.

\section{Species recorded}

Belemnitella woodi and Belemnitella ex gr. langei sensu Christensen, 1995.

\section{Examples}

Nouvelles Chalk Formation (uppermost $4 \mathrm{~m}$, with exception of hardground at top of unit), CCC pit, Harmignies, Belgium; Gulpen Formation, Zeven Wegen Member (10-28 m above base of unit), former CPL SA quarry, Haccourt, Belgium.

\section{References}

Christensen (1999) and Keutgen \& Jagt (1999).

\section{Remarks}

Christensen (1995) distinguished early and late forms of Blt. woodi, the former being less slender than the latter. In the former CPL SA quarry, the section between 6 and $17 \mathrm{~m}$ above the base of the member yielded early forms, and that between 17 and $28 \mathrm{~m}$, late forms of Blt. woodi.

Within the uppermost Blt. woodi Zone, Belemnitella ex gr. langei occurs in the Mons Basin, a form unknown from elsewhere in the study area (Fig. 4). According to Christensen (1999), it is characterised by a small and slender to very slender guard, which is slightly lanceolate in ventral view. Because the internal characters are known only from a single specimen, it is presumed that the Schatzky Distance is small and the fissure

\begin{tabular}{|c|c|c|c|c|c|}
\hline & \begin{tabular}{|c|} 
Biozones of Läg- \\
erdorf - Krons- \\
moor
\end{tabular} & $\begin{array}{c}\text { Lithostratigra- } \\
\text { phical members } \\
\text { of Norfolk }\end{array}$ & $\begin{array}{c}\text { Belemnella } \\
\text { zones of } \\
\text { Norfolk }\end{array}$ & $\begin{array}{c}\text { Belemnitella } \\
\text { zones of } \\
\text { Norfolk }\end{array}$ & $\begin{array}{c}\text { Belemnitezones of } \\
\text { Mons basin and MAL } \\
\text { area }\end{array}$ \\
\hline \multirow{6}{*}{ 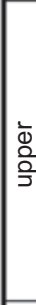 } & pseudobtusa & $\begin{array}{l}\text { Sidestrand } \\
\text { Chalk (pars) }\end{array}$ & pseudobtusa & \multirow{3}{*}{ minor II } & \multirow{3}{*}{ Blt. minor II } \\
\hline & lanceolata & \multirow{3}{*}{$\begin{array}{l}\text { Paramoudra } \\
\text { Chalk }\end{array}$} & & & \\
\hline & grimmensis/ & & & & \\
\hline & granulosus & & & \multirow{3}{*}{ minor I } & \multirow{3}{*}{ Blt. minor I } \\
\hline & langei & \multirow{2}{*}{$\begin{array}{c}\text { Beeston } \\
\text { Chalk }\end{array}$} & & & \\
\hline & polyplocum & & & & \\
\hline \multirow{4}{*}{$\sum_{3}^{\bar{\Phi}}$} & vulgaris & $\begin{array}{l}\text { Weybourne } \\
\text { Chalk }\end{array}$ & & \multirow{2}{*}{ woodi } & \multirow{2}{*}{ Blt. woodi } \\
\hline & stobaei/basiplana/ & \multirow{3}{*}{$\begin{array}{l}\text { Pre-Weybourne } \\
\text { Chalk }\end{array}$} & & & \\
\hline & spiniger & & & \multirow{2}{*}{ mucronata } & \multirow{2}{*}{ Blt. mucronata } \\
\hline & conica/mucronata: & & & & \\
\hline
\end{tabular}

Fig. 4. Stratigraphical correlation diagram for the upper Campanian (sources: Schulz, 1979; Schulz et al., 1984; Johansen \& Surlyk, 1990; Christensen, 1999; Niebuhr, 2006). Abbreviations: Bln. = Belemnella; Blt. = Belemnitella; $M A L=$ Maastricht-Aachen-Liège area. Dots indicate that the presence of a species at this level is uncertain. Vertical axis not to scale.

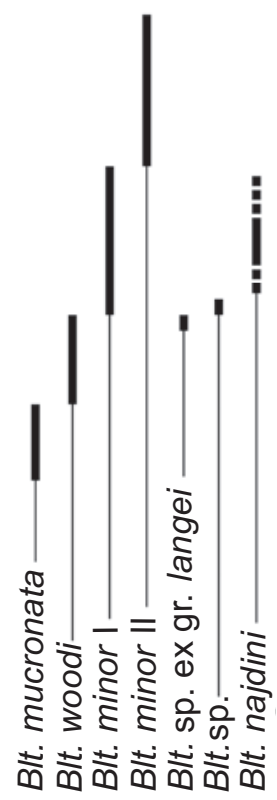


angle large. Due to the limited number of specimens, Blt. ex gr. langei cannot be assigned to any known species of the genus with certainty (Christensen, 1999).

\section{Lower upper/upper upper Campanian boundary}

The base of the upper upper Campanian is usually defined by the FAD of Nostoceras (Bostrychoceras) polyplocum (Roemer, 1841). In Norfolk, Blt. minor I Jeletzky, 1951 first appears in the Catton Sponge Bed, from which many specimens of $N$. (B.) polyplocum probably originated as well (Johansen \& Surlyk, 1990). That particular bed forms the top of the Weybourne Chalk Member in Norfolk. The FAD of Blt. minor I represents an excellent approximation for the base of the upper upper Campanian (Figs 2, 4).

\section{Upper upper Campanian belemnite zones}

Belemnitella minor I Zone

\section{Age}

Late late Campanian.

\section{Species recorded}

Belemnitella minor I and Belemnitella najdini Kongiel, 1962.

\section{Examples}

Nouvelles Chalk Formation (hardground at top of unit), CCC pit, Harmignies, Belgium; Spiennes Chalk Formation (basal $10 \mathrm{~m}$ ), CCC pit, Harmignies, Belgium; Gulpen Formation, Beutenaken Member at Slenaken and Bovenste Bos, the Netherlands.

\section{References}

Christensen (1999), Keutgen \& Jagt (1999) and Keutgen et al. (2010).

\section{Remarks}

Apart from Blt. minor I, Blt. najdini occurs in this zone, but this has so far only been identified in the MAL area. The Limburg material of Blt. najdini corresponds well with specimens from the upper Beeston Chalk Member of Norfolk, as illustrated by Christensen (1995). With respect to its distribution in Norfolk, it is assumed that Blt. najdini appeared later than Blt. minor I (Fig. 4).

From c. $1.8 \mathrm{~m}$ above the base of the Spiennes Chalk Formation (CCC pit, Harmignies), Christensen (1999) recorded, under the name of Belemnitella sp., two specimens of the members of the Belemnitella mucronata group, characterised by their large and stout rostra (Birkelund indices of 2.9 and 3.2). He assumed these specimens to be related either to Blt. mucronata or to Blt. woodi, the small number of specimens on record precluding a more detailed identification.
Bless et al. (1991) noted, as Blt. gr. mucronata, a specimen from the uppermost portion of the 'Craie blanche' as exposed at Orp-le-Petit (eastern Brabant Massif, Belgium), seemingly resembling Blt. minor I. This specimen would favour a correlation of the uppermost portion of the 'Craie blanche' either with the hardground at the top of the Nouvelles Chalk Formation or with the Spiennes Chalk Formation in the Mons Basin or with the Beutenaken Member in the MAL area (Bless et al., 1991), a preliminary interpretation, here incorporated in Fig. 2.

Belemnitella minor II Zone

\section{Age}

Latest late Campanian.

\section{Species recorded}

Belemnitella minor II Christensen, 1995 and Belemnella (Pachybelemnella) inflata (Arkhangelsky, 1912).

\section{Examples}

Spiennes Chalk Formation (top $1 \mathrm{~m}$ ), La Malogne-Cuesmes, Belgium; Spiennes Chalk Formation (topmost portion), André et Fils pit no. 6, Ciply, southern Belgium.

\section{Reference}

Christensen (1999).

\section{Remarks}

The present definition of the top of this zone differs significantly from that originally proposed by Christensen (1995, 1999) for the Norfolk area. While the Blt. minor II Zone of Christensen (1999, fig. 8) covered the upper portion of the Paramoudra Chalk Member and the Bln. lanceolata, Bln. pseudobtusa and most of the Bln. obtusa zones of the Sidestrand Chalk Member of Norfolk, the present interpretation defines the top of this zone by the FAD of Belemnella obtusa Schulz, 1979 (Figs 4, 5).

On the basis of members of Belemnella present in the Blt. minor II Zone in Norfolk, this zone may be subdivided informally in the study area into an upper portion with early representatives of that genus and a lower portion without. As formerly defined, the FAD of the genus Belemnella marks the base of the Maastrichtian Stage.

In the study area, the Blt. minor II Zone has so far been identified only in the topmost Spiennes Chalk Formation of the Mons Basin (Christensen, 1999). However, corresponding deposits must have been present locally during the early late Maastrichtian in the Beutenaken area (MAL area), because a remanié fauna with common Blt. minor II and rare Bln. inflata has recently been recorded from the base of the Vijlen Member in the Pesaken-Crapoel road section (Keutgen et al., 2010). 


\section{Campanian/Maastrichtian boundary}

At the Symposium on Cretaceous Stage Boundaries (Brussels, September 1995), the section at Tercis les Bains, near Dax (Landes, southwest France), was proposed as the Global Standard Stratotype Section and Point for this boundary; this was later ratified (Walaszczyk et al., 2002). However, correlation of this boundary with the belemnite zones established in northwest Europe was fraught with difficulties. On ammonite evidence, Niebuhr (2003, 2004) placed the Campanian/ Maastrichtian boundary (as defined at Tercis) close to the top of the Bln. pseudobtusa Zone at Kronsmoor, which is well in line with earlier interpretations by Hancock et al. (1993) and Burnett et al. (1998). Ogg et al. (2004) dated the Campanian/ Maastrichtian boundary at $70.6 \mathrm{Ma}$, close to the base of the Bln. obtusa Zone. This interpretation is followed herein.

\section{Lower Maastrichtian belemnite zones}

\section{Belemnella obtusa Zone}

\section{Age}

Early early Maastrichtian.

\section{Species recorded}

Belemnella (Pachybelemnella) obtusa Schulz, 1979, Belemnitella minor II and Belemnitella pulchra Schulz, 1982.

\section{Examples}

Ciply-Malogne Phosphatic Chalk Formation at La Malogne, André et Fils pits and Vienne pit near Ciply, southern Belgium.

\section{Reference}

Christensen (1999).

\section{Remarks}

Similar to the Blt. minor II Zone, in situ occurrences of the present zone are known exclusively from the Mons Basin, while in the MAL area this zone has been identified in remanié belemnite material (Keutgen et al., 2010). While Bln. obtusa and Blt. minor II have been documented from the base of the Vijlen Member at several outcrops in the Beutenaken area, Blt. pulchra appears confined to the Bln. obtusa Zone in the Mons Basin.

Four remanié specimens of Belemnella (Bln.) lanceolata (Von Schlotheim, 1813) have been collected from the basal Vijlen Member at the Bovenste Bos quarry (3) and near Beutenaken (1) in the MAL area, where they co-occur with Bln. obtusa (Keutgen \& Van der Tuuk, 1991). They have been remeasured for the present study and the mean values of this small sample for Lsn (c. $74 \mathrm{~mm}$ ) and $\mathrm{AV}$ (c. 21\%) are more advanced than those of Bln. lanceolata from the Bln. lanceolata Zone at Balsvik (southern Sweden) and Kronsmoor (Schulz, 1979). They indicate either the Bln. pseudobtusa or the early Bln. obtusa zones sensu germanico and are tentatively considered to originate from the Bln. obtusa Zone.

Belemnella ex gr. sumensis/cimbrica Zone

\section{Age}

Late early Maastrichtian.

\section{Species recorded}

Belemnella (Pachybelemnella) ex gr. sumensis Jeletzky, 1949/ cimbrica Birkelund, 1957 and Belemnella (Belemnella) praearkhangelskii Naidin, 1964.

\section{Example}

Gulpen Formation, Vijlen Member (unit 3), temporarily exposed sections at Aachen-Schurzelterstraße, Germany.

\section{Reference}

Keutgen et al. (2010).

\section{Remarks}

Belemnites which match the population concepts of both Bln. sumensis and Bln. cimbrica are common within the Vijlen Member. However, most of the samples recorded in the literature (Keutgen \& Van der Tuuk, 1991; Keutgen, 1997) have recently been considered to consist of reworked material. Keutgen et al. (2010) mentioned but a single larger sample of Belemnella collected from a level within the Vijlen Member (unit 3) below the FAD of Belemnitella junior. This temporary section at Aachen-Schurzelterstraße yielded Belemnella ex gr. sumensis/cimbrica together with a well-preserved specimen of the typically early Maastrichtian index scaphitid ammonite Acanthoscaphites tridens (Kner, 1848). The mean values of characteristic parameters of the Schurzelterstraße sample indicate either a late form of Bln. sumensis or, alternatively, Bln. cimbrica; a more precise identification is impossible (Keutgen et al., 2010).

From unit 4 of the Vijlen Member at Altembroeck ('s-Gravenvoeren, Fouron-le-Comte), Keutgen (1997) noted early forms of Bln. sumensis (common) and of Bln. praearkhangelskii (very rare). These species co-occur with typically late Maastrichtian Blt. junior and Blt. lwowensis, which is why representatives of the genus Belemnella have been considered reworked (Keutgen et al., 2010). Belemnella praearkhangelskii is known in the Kronsmoor and Hemmoor sections from the middle sumensis Zone and has also been identified in Rügen (northern Germany). It is assumed that this species entered Germany and the study area during a short time interval, corresponding to the middle sumensis Zone sensu germanico. 


\section{Lower/upper Maastrichtian boundary}

At the Symposium on Cretaceous Stage Boundaries (Brussels, September 1995), a formal proposal for the definition of the base of the upper Maastrichtian could not be given (0din et al., 1996). At the ENCI-Heidelberg Cement Group quarry (Maastricht, the Netherlands), the position of the lower/upper Maastrichtian boundary has been drawn, on benthic foraminiferal evidence, at the top of the interval with both Bolivinoides draco draco (Marsson, 1878) and Stensioeina pommerana Brotzen, 1936, i.e. within unit 6 of the Vijlen Member (Jagt, 2010). At Hemmoor (northwest Germany), Hofker (1961) found the highest occurrence of Stensioeina to equate with the lower/upper Maastrichtian boundary, at the base of marl bed T100, while Weiss (1999) pointed out that $S$. pommerana suddenly disappeared there near the top of the Belemnella cimbrica Zone, i.e., c. $10 \mathrm{~m}$ below marl bed T100. Strontium isotope data (Vonhof et al., 2011) corroborate the correlation of the lower/ upper Maastrichtian boundary (as defined at Hemmoor) with a level either close to the base of or within unit 6 of the Vijlen Member.

Despite this, for over half a century, the base of the upper Maastrichtian in northwest Europe was defined by the FAD of Belemnitella junior. In the present study, this preliminary definition is accepted for the Mons, Brabant-Méhaigne and MAL areas. At Hemmoor, Blt. junior first appears about $4.9 \mathrm{~m}$ above marl bed T100 (Christensen et al., 2004), while in the MAL area the first representatives of Blt. junior appear close to the base of unit 4 of the Vijlen Member, about $20 \mathrm{~m}$ below the lower limit of unit 6 (Keutgen et al., 2010). Additional work is needed in order to explain the inconsistencies between belemnite stratigraphy on the one hand, foraminiferal zones and strontium isotope curves on the other.

\section{Upper Maastrichtian belemnite zones}

Belemnitella junior

\section{Age}

Early late to late late Maastrichtian.

\section{Species recorded}

Belemnitella junior and Belemnitella lwowensis Naidin, 1952.

\section{Examples}

Gulpen Formation, Vijlen Member (unit 4) at Altembroeck, 's-Gravenvoeren (Fouron-le-Comte, Belgium), Aachen-HansBöckler-Allee; Gulpen Formation, Vijlen (units 5-6), Lixhe and Lanaye members, former CPL SA quarry, Haccourt, Belgium; Maastricht Formation, Valkenburg, Gronsveld, Schiepersberg, Emael, Nekum members and lower portion of the Meerssen Member, ENCI-Heidelberg Cement Group quarry near Maastricht, the Netherlands.

\section{References}

Jagt (1999), Christensen et al. (2004) and Keutgen et al. (2010).

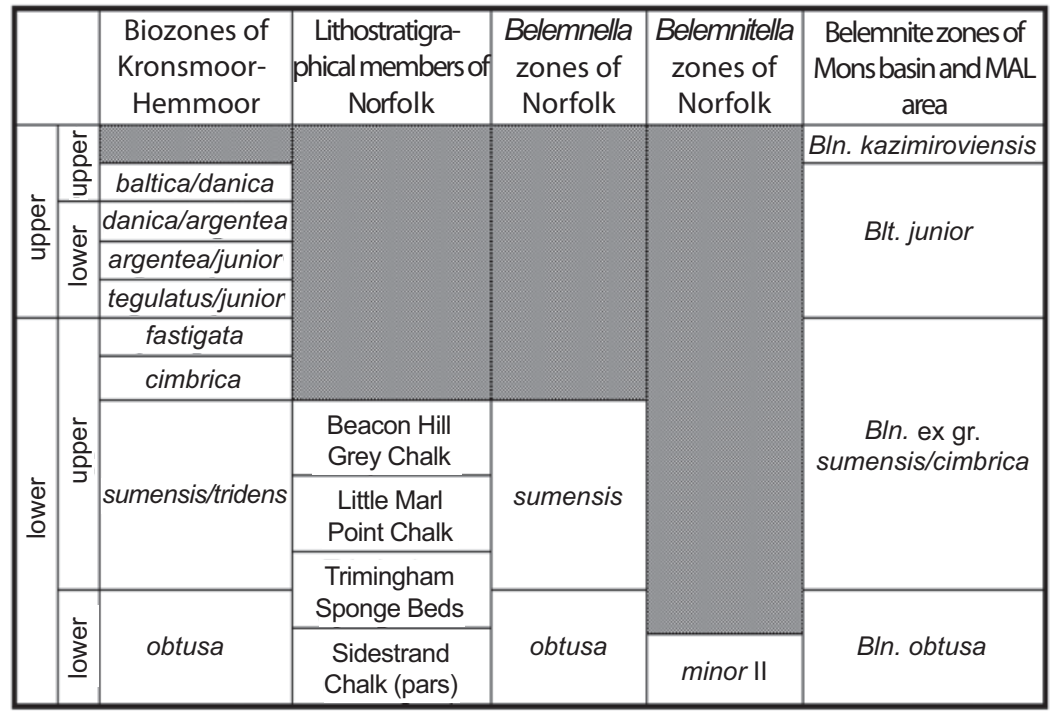

Fig. 5. Stratigraphical correlation diagram for the Maastrichtian (sources: Schulz, 1979; Schulz \& Schmid, 1983; Johansen \& Surlyk, 1990; Christensen, 1995; Niebuhr, 2006; Keutgen et al., 2010). Abbreviations: $B l n .=$ Belemnella; $B l t .=$ Belemnitella; MAL = Maastricht-Aachen-Liège area. Dots indicate that the presence of a species at this level is uncertain. vertical axis not to scale.

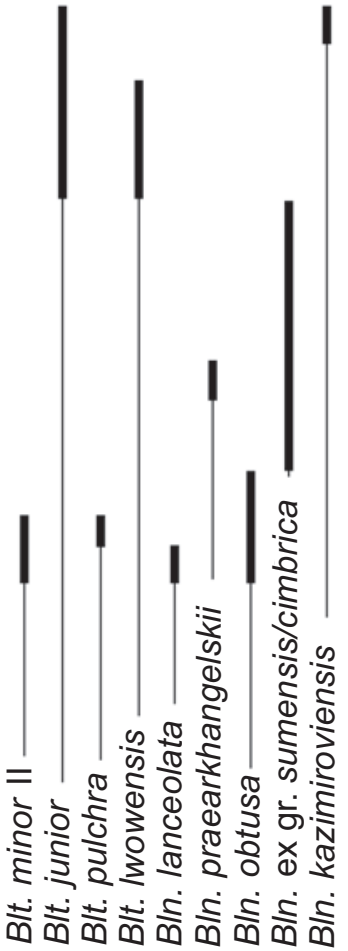




\section{Remarks}

The earliest representatives of Blt. junior and Blt. lwowensis are known from unit 4 of the Vijlen Member in the MAL area. In the Brabant-Méhaigne area and the Mons Basin, upper Maastrichtian deposits comprise only the Jauche Member (with Blt. junior) and the Saint-Symphorien Calcarenite Formation, which may correspond with portions of the Lanaye Member and lower Valkenburg Member in the MAL area (Bless et al., 1991).

While Blt. junior is known from the eponymous zone, the distribution of Blt. lwowensis is far less well documented. According to Christensen et al. (2004), that species ranges at least up to the middle portion of the Maastricht Formation (Emael Member).

\section{Belemnella kazimiroviensis}

\section{Age}

Latest late Maastrichtian.

\section{Species recorded}

Belemnella (Neobelemnella) kazimiroviensis (Skołozdrówna, 1932) and Belemnitella junior.

\section{Example}

Maastricht Formation, upper portion of Meerssen Member, former Ankerpoort-Curfs quarry, Geulhem, and ENCI-HeidelbergCement Group quarry, Maastricht, the Netherlands.

\section{Reference}

Jagt $(1996,1999)$.

\section{Remarks}

Belemnella kazimiroviensis first appears at the top of subunit IVf-3 or the base of subunit IVf- 4 of the Meerssen Member and becomes extinct at the Cretaceous/Paleogene boundary, which equates with the lower limit of subunit IVf-7 (= Berg en Terblijt Horizon) within the highest Meerssen Member (Jagt, 1999). Belemnite guards accumulated on top of the Berg en Terblijt Horizon are mostly corroded and some of them are bored by other organisms, indicating condensation, if not reworking. Belemnites found above the Vroenhoven Horizon within the lowermost Geulhem Member (Houthem Formation; lowermost Paleocene, lower Danian) are frequently fragmentary and rounded and can obviously be considered reworked.

Christensen $(1996,1997)$ showed the distribution of Bln. kazimiroviensis between the eastern part of the Russian Platform and the Maastricht area to be highly diachronous. Consequently, this species should not be used as a zonal index for long-distance correlations. Belemnitella junior ranges throughout the Bln. kazimiroviensis Zone, but is never common.

\section{Discussion}

In the Santonian-Maastrichtian interval of the Mons Basin and the Brabant-Méhaigne and MAL areas, thirteen belemnite zones can be distinguished; three in the Santonian (Gonioteuthis w. westfalica, G. westfalicagranulata and G. granulata), six in the Campanian (G. granulataquadrata, G. quadrata, Blt. mucronata, Blt. woodi, Blt. minor I and Blt. minor II), and four in the Maastrichtian (Bln. obtusa, Bln. ex gr. sumensis/cimbrica, Blt. junior and Bln. kazimiroviensis). Within these, twenty-two species of belemnitellid have been documented, of the genera Actinocamax, Gonioteuthis, Belemnitella and Belemnella. Correlations of these zones with those established in Norfolk (southeast England; see Christensen, 1991, 1995) and northern Germany (see Schulz, 1979; Schulz et al., 1984; Niebuhr, 2006) is illustrated in Figs 3-5.

A comparison of the belemnite faunas of the study area has revealed that most of the belemnitellid species occur throughout this area, provided that the proper strata have been preserved. However, A. verus, Belemnitella sp., Blt. ex gr. langei, Blt. najdini, Blt. pulchra, Blt. lwowensis and Bln. lanceolata have a more restricted distribution in the study area, as follows:

Actinocamax verus has been recorded from the Mons Basin and the Brabant-Méhaigne area, but is unknown from the MAL area. This is, at least in part, due to the fact that the nearshore, sandy Aachen Formation, of Santonian age, has not yielded any belemnites to date. Santonian belemnitellids are known solely from levels penetrated in the former Houthalen and Zolder/ Voort mine shafts, from where $G$. westfalicagranulata has been recorded. The Lonzée Member, in contrast, yields specimens from the stratigraphically older G. w. westfalica Zone. Hence, it cannot be ruled out that $A$. verus actually is restricted to that zone in the study area. Its absence from collections from the mine shafts would favour such an interpretation. Robaszynski et al. (2002) mentioned A. verus from the upper ConiacianSantonian Saint-Vaast Chalk Formation in the Mons Basin, but no representatives of the genus Gonioteuthis. Additional studies of belemnites from the Saint-Vaast Chalk Formation are needed in order to determine if Gonioteuthis is really absent or not.

To date, Belemnitella ex gr. langei has only been recorded from the uppermost portion of the Nouvelles Chalk Formation in the Mons Basin. Thus, this species either is to be considered stenoecious or the corresponding deposits of the upper Blt. woodi Zone were eroded during the middle to late late Campanian regression in the MAL and Brabant-Méhaigne areas.

Belemnitella najdini is known exclusively from the Beutenaken Member in the MAL area, being absent from the Spiennes Chalk Formation in the Mons Basin. Christensen (1997) mentioned that small species of Belemnitella, i.e., Blt. langei, Blt. najdini and Blt. ex gr. langei/najdini (the latter also referred to Blt. najdini by Keutgen \& Jagt, 1999) immigrated into the Norfolk area (England) three times during the late late Campanian, implying that Blt. najdini required special environmental conditions; seemingly such were not fulfilled in the Mons Basin at the time. 
Of Belemnitella sp. only two specimens have been recorded from the lower Spiennes Chalk Formation of the CCC pit (Harmignies, Mons Basin), showing this species to be very rare, which may explain the lack of records from the BrabantMéhaigne and MAL areas. In addition, it is quite possible that deposition of the Beutenaken Member in the MAL area started later than that of the Spiennes Chalk Formation at Harmignies.

Belemnitella pulchra is a very rare latest Campanian-early Maastrichtian species, with records from Poland, Germany and Belgium. Its general rarity may explain the lack of records from the MAL area, where remanié early Maastrichtian belemnites are known from the Vijlen Member. Of note is that Keutgen et al. (2010) mentioned two specimens, referred to as Blt. ex gr. pulchra/lwowensis, from the Vijlen Member at Altembroeck, which could be interpreted as remanié Blt. pulchra.

At present, Blt. lwowensis is known exclusively from the MAL area. However, belemnites from the Jauche Member and Saint-Symphorien Calcarenite Formation should be studied in more detail in order to determine whether Blt. lwowensis is really absent there or not.

So far, of Belemnella lanceolata remanié specimens have been shown to co-occur with early forms of Bln. obtusa in the Vijlen Member near Beutenaken (MAL area). Schulz (1979) identified $B l n$. lanceolata from the base of the Bln. lanceolata Zone up to the lower Bln. obtusa Zone at Kronsmoor, which corresponds well with the co-occurrence of early forms of Bln. obtusa and $B l n$. lanceolata in the MAL area. The Ciply-Malogne Phosphatic Chalk Formation of the Mons Basin was dated as middle Bln. obtusa Zone (Christensen, 1999), which is younger than the documented range of Bln. lanceolata. In consequence, Bln. lanceolata may not be expected in these deposits.

In conclusion, the absence of some belemnite species in certain regions of the study area can in many cases be explained either by absence of the proper deposits (hiatuses), a general rarity of the species, or a poor knowledge of the belemnite assemblages in certain lithological units. For one or two species, Blt. najdini and possibly Blt. ex gr. langei, environmental aspects could have affected their distributional pattern. For Blt. najdini in particular, this conclusion may be of importance, because this species is considered an index belemnite of the latest Campanian.

The belemnitellid fauna of the study area closely resembles that of Norfolk (Christensen, 1991, 1995), but appears to have been less diverse. Only a single species, Blt. ex gr. langei (from the uppermost Nouvelles Chalk Formation) has not been recorded from Norfolk. For comparison, Belemnellocamax ex gr. grossouvrei (Janet, 1891), Goniocamax lundgreni (Stolley, 1897), Belemnitella propinqua (Moberg, 1885), Belemnitella langei Jeletzky, 1948, Belemnitella pauli Christensen, 1995 and Belemnella (Pachybelemnella) pseudobtusa Schulz, 1979, all documented for Norfolk, have not been recorded from the Mons Basin and the Brabant-Méhaigne and MAL areas. The absence of $B x$. ex gr. grossouvrei may be explained by its overall rarity (compare Jagt et al., 2009), while Gx. lundgreni and Blt. propinqua occur mainly in the Central Russian Subprovince and southern Sweden. Their presence in southern England may be seen as an occasional immigration pulse from the north that did not reach the study area. The concept of Blt. langei has differed among authors, and, hence, reliable data on its distribution are not available. Preliminary data indicate that it occurs mainly in the Central Russian Subprovince and may have reached England from the north, similar to Gx. lundgreni and Blt. propinqua. In western Europe, it has so far been identified only in Norfolk. In addition, Blt. pauli appears to be confined to Norfolk, where it is rare in the Beeston and lowermost Paramoudra Chalk members. The absence of Blt. pauli in the study area may be related to its limited distribution, in addition to its primary rarity. The absence of Bln. pseudobtusa in the Mons Basin and in the MAL area is due to the rarity/ absence of outcrops of latest Campanian deposits in these areas.

A comparison of the belemnitellid fauna of the MAL, Brabant-Méhaigne and Mons areas with that of northern Germany has revealed close similarities, but differences exist in particular during the late Campanian and early Maastrichtian. Belemnitella woodi, Blt. minor I, Blt. minor II and Blt. najdini are unknown from the Lägerdorf-Kronsmoor section, while Blt. misburgensis, Blt. langei sensu Schulz, 1978, Blt. schulzi Christensen, 2000a, a number of species of Belemnella and Fusiteuthis polonica Kongiel, 1962 (see Christensen, 2002) have never been recorded from the Mons Basin and the MAL area.

Belemnitellid cephalopods are reliable biostratigraphic tools, especially when developmental lineages within genera are considered. However, the present study has demonstrated that difficulties in correlation may occur when a zonal boundary is defined by the appearance or disappearance of a genus. For example, the FAD of Bln. kazimiroviensis is distinctly diachronous in the Central European Subprovince. It ranges through the entire upper Maastrichtian in eastern Europe (e.g. Poland), occurs in the upper upper Maastrichtian of Danemark, while in the type Maastricht area it is restricted to the uppermost portion of the upper upper Maastrichtian (Naidin, 1975; Christensen, 1996). The FAD of Belemnella within the uppermost Campanian is also slightly diachronous. While it defines the base of the Bln. lanceolata Zone at Kronsmoor (northwest Germany), contemporary deposits in Denmark have yielded exclusively Blt. schulzi (Christensen, 2000a). Whether this genus appeared later in Norfolk and the study area than in northwest Germany is open to discussion, because deposits of the critical interval are either not well exposed or have not been preserved.

The uncertainties related to the definition of the lower/ upper Campanian boundary by belemnites in the study area have been discussed previously. This boundary is usually defined by the LAD of the genus Gonioteuthis (Jeletzky, 1958). However, it remains to be proved if the two regional subspecies of $G$. quadrata, viz. G. quadrata gracilis and G. quadrata scaniensis, did indeed disappear simultaneously. 


\section{Acknowledgements}

The present paper is based on numerous contributions by various scholars who dedicated their scientific careers to the Upper Cretaceous; first and foremost it is dedicated to the memory of Sjeuf and Werner Felder. I also wish to acknowledge Walter Kegel Christensen (deceased), Max-Gotthard Schulz (deceased) and Friedrich Schmid for their fundamental work on belemnites in the study area, and John W.M. Jagt for editorial and linguistic comments on an earlier version of the typescript.

\section{References}

Albers, H.-J., 1976. Feinstratigraphie, Faciesanalyse und Zyklen des Untercampans (Vaalser Grünsand = Hervien) von Aachen und dem niederländisch-belgischen Limburg. Geologisches Jahrbuch A34: 3-68.

Arkhangelsky, A.D., 1912. Verkhnemelovyya otlozheniya vostoka evropejskoy rossii. Materialy dlja Geologii Rossii 25: xxv + 1-631.

Bayle, E., 1878. Fossiles principaux der terrains de la France. Explication de la carte géologique de la France 4(1), Atlas: 79 pls.

Birkelund, T., 1957. Upper Cretaceous belemnites from Denmark. Biologiske Skrifter fra det Kongelige Danske Videnskabernes Selskab 9: 1-69.

Bless, M.J.M., Felder, P.J. \& Jagt, J.W.M., 1991. Repeated Tethyan influences in the early Campanian to middle late Maastrichtian successions of Folx-lesCaves and Orp-le-Petit (eastern Brabant Massif, Belgium). Annales de la Société géologique de Belgique 113: 179-197.

Bless, M.J.M., Felder, P.J. \& Meessen, J.P.M.T., 1987. Late Cretaceous sea level rise and inversion: their influence on the developmental environment between Aachen and Antwerp. Annales de la Société géologique de Belgique 109: 333-355.

Brotzen, F., 1936. Foraminiferen aus dem Schwedischen untersten Senon von Eriksdal in Schonen. Årsbok Sveriges Geologiska Undersökning C396: 1-206.

Burnett, J.A., Gallagher, L.T. \& Hampton, M.J., 1998. Upper Cretaceous. In: Brown, P.R. (ed.): Calcareous nannofossil biostratigraphy (British Micropalaeontological Society, Publication Series Vol. 6). Chapman and Hall, London: 132-199.

Christensen, W.K., 1975. Upper Cretaceous belemnites from the Kristianstad area in Scania. Fossils and Strata 7: 1-69.

Christensen, W.K., 1986. Upper Cretaceous belemnites from the Vomb Trough in Scania, Sweden. Sveriges geologiska Undersökning Ca57: 1-57.

Christensen, W.K., 1991. Belemnites from the Coniacian to Lower Campanian chalks of Norfolk and southern England. Palaeontology 34: 695-749.

Christensen, W.K., 1993. Upper Cretaceous belemnitellids from the Båstad basin, southern Sweden. Geologiska Föreningens i Stockholm Förhandlingar 115: 39-57.

Christensen, W.K., 1994. Upper Cretaceous belemnites from Lonzée (SE Belgium) and their stratigraphical significance. Bulletin de l'Institut royal des Sciences naturelles de Belgique, Sciences de la Terre 64: 151-158.

Christensen, W.K., 1995. Belemnitella from the Upper Campanian and Lower Maastrichtian Chalk of Norfolk, England. Special Papers in Palaeontology 51: 1-84.

Christensen, W.K., 1996. A review of the Upper Campanian and Maastrichtian belemnite biostratigraphy of Europe. Cretaceous Research 17: 751-766.
Christensen, W.K., 1997. The Late Cretaceous belemnite family Belemnitellidae: taxonomy and evolutionary history. Bulletin of the Geological Society of Denmark 44: 59-88.

Christensen, W.K., 1999. Upper Campanian and Lower Maastrichtian belemnites from the Mons Basin, Belgium. Bulletin de l'Institut royal des Sciences naturelles de Belgique, Sciences de la Terre 69: 97-131.

Christensen, W.K., 2000a. Belemnitella schulzi sp. nov. from the uppermost Campanian and lowest Maastrichtian chalks of northwest Germany and Denmark. Acta Geologica Polonica 50: 55-66.

Christensen, W.K., 2000b. Gradualistic evolution in Belemnitella from the middle Campanian of Lower Saxony, NW Germany. Bulletin of the Geological Society of Denmark 47: 135-163.

Christensen, W.K., 2002. Fusiteuthis polonica, a rare and unusual belemnite from the Maastrichtian. Acta Palaeontologica Polonica 47: 679-683.

Christensen, W.K. \& Schmid, F., 1987. The belemnites of the Vaals Formation from the C.P.L. quarry at Hallembaye in Belgium - taxonomy, biometry and biostratigraphy. Geologisches Jahrbuch A94: 3-37.

Christensen, W.K., Schmid, F. \& Schulz, M.-G., 2004. Belemnitella from the Upper Maastrichtian of Hemmoor, Northwest Germany. Geologisches Jahrbuch A157: 23-67.

Coquand, H., 1859. Synopsis des animaux et des végétaux fossiles observés dans la formation crétacée du Sud-Ouest de la France. Bulletin de la Société géologique de France (2)16: 945-1023.

De Blainville, H.M.D., 1827. Mémoire sur les Bélemnites, considerées zoologiquement et géologiquement. F.G. Levrault, Paris: 1-136.

d'Orbigny, A.D., 1840-1842. Paléontologie française; Terrains crétacés, 1. Céphalopodes. Masson (Paris): 1-120 (1840); 121-430 (1841); 431-662 (1842).

Ernst, G. \& Schulz, M.-G., 1974. Stratigraphie und Fauna des Coniac und Santon im Schreibkreide-Richtprofil von Lägerdorf (Holstein). Mitteilungen aus dem Geologisch-Paläontologischen Institut der Universität Hamburg 43: 5-60.

Felder, P.J., 1997. The Vijlen Chalk Member (Maastrichtian, Late Cretaceous) in the Meuse-Rhine Euregion. Annales de la Société géologique de Belgique 119 (for 1996): 119-133.

Felder, P.J., 2001. Bioklasten-stratigrafie of ecozonatie voor het krijt (sic) (Santoniaan-Campaniaan-Maastrichtiaan) van Zuid-Limburg en oostelijk België. Memoirs of the Geological Survey of Belgium 47: 1-141.

Felder, W.M. \& Bosch, P.W., 2000. Geologie van Nederland, Deel 5: Krijt van ZuidLimburg. Nederlands Instituut voor Toegepaste Geowetenschappen (Utrecht): 1-192.

Fletcher, T.P. \& Wood, C.J., 1978. Cretaceous rocks. In: Wilson, H.E. \& Manning, P.I. (eds): Geology of the Causeway Coast. Memoir of the Geological Survey of Northern Ireland, Sheet 7(2): 85-115.

Gale, A.S., Montgomery, P., Kennedy, W.J., Hancock, J.M., Burnett, J.A. \& McArthur, J.M., 1995. Definition and global correlation of the SantonianCampanian boundary. Terra Nova 7: 611-622.

Gale, A.S., Kennedy, W.J., Lees, J.A., Petrizzo, M.R. \& Walaszczyk, I., 2007. An integrated study (inoceramid bivalves, ammonites, calcareous nannofossils, planktonic foraminifera, stable carbon isotopes) of the Ten Mile Creek section, Lancaster, Dallas County, north Texas, a candidate global boundary stratotype section and point for the base of the Santonian stage. Acta Geologica Polonica 57: 113-160. 
Gale, A.S., Hancock, J.M., Kennedy, W.J., Petrizzo, M.R., Lees, J.A., Walaszczyk, I. \& Wray, D.S., 2008. An integrated study (geochemistry, stable oxygen and carbon isotopes, nannofossils, planktonic foraminifera, inoceramid bivalves, ammonites and crinoids) of the Waxahachie Dam Spillway section, north Texas: a possible boundary stratotype for the base of the Campanian Stage. Cretaceous Research 29: 131-167.

Hancock, J.M., Peake, N.B., Burnett, J., Dhondt, A.V., Kennedy, W.J. \& Stokes, R.B., 1993. High Cretaceous biostratigraphy at Tercis, south-west France. Bulletin de l'Institut royal des Sciences naturelles de Belgique, Sciences de la Terre 63: 133-148.

Hofker, J., 1961. Die Foraminiferen-Fauna der Gruben Hemmoor und Basbeck. Paläontologische Zeitschrift 35: 123-145.

Jagt, J.W.M., 1984. Nogmaals de groeve Ciments Portland Liègeois (sic) bij Hallembaye: biostratigrafische aantekeningen. Grondboor en Hamer 38: 149-158.

Jagt, J.W.M., 1996. Late Maastrichtian and Early Palaeocene index macrofossils in the Maastrichtian type area (SE Netherlands, NE Belgium). In: Brinkhuis, H. \& Smit, J. (eds): The Geulhemmerberg Cretaceous/Tertiary boundary section (Maastrichtian type area, SE Netherlands). Geologie en Mijnbouw 75: 153-162.

Jagt, J.W.M., 1999. Late Cretaceous-Early Palaeogene echinoderms and the K/T boundary in the southeast Netherlands and northeast Belgium - Part 1. Introduction and stratigraphy. Scripta Geologica 116: 1-57.

Jagt, J.W.M., 2010. Upper Cretaceous and Lower Paleogene in the type area of the Maastrichtian stage (70.6-65.5 Ma). Berichte-Reports, Institut für Geowissenschaften, Universität Kiel 23: 1-21.

Jagt, J.W.M., Burnett, J., Kennedy, W.J., 1995a. Campanian ammonites and nannofossils from southern Limburg, the Netherlands. Mededelingen Rijks Geologische Dienst 53: 49-63.

Jagt, J.W.M., Felder, W.M. \& Meessen, J.P.M.T., 1987. Het Boven-Campanien in Zuid-Limburg (Nederland) en Noordoost België. Natuurhistorisch Maandblad 76: 94-110.

Jagt, J.W.M., Jagt-Yazykova, E.A. \& Van Neer, R., 2009. Belemnellocamax ex gr. grossouvrei, a rare mid-Campanian belemnitellid (Cephalopoda, Coleoidea) from the Hannover area, Northern Germany. Byulleten' Moskovskogo Obshchestva Ispytatelej Prirody, Otdel Geologicheskii 84: 78-82.

Jagt, J.W.M., Kennedy, W.J., Burnett, J.A., Christensen, W.K. \& Dhondt, A.V., 1995b. Santonian macrofauna and nannofossils from northeast Belgium. Bulletin de l'Institut royal des Sciences naturelles de Belgique, Sciences de la Terre 65: 127-137.

Janet, C., 1891. Note sur trois nouvelles bélemnites sénoniennes. Bulletin de la Société géologique de France 19: 716-721.

Jeletzky, J.A., 1948. Zur Kenntnis der Oberkreide der Dnjepr-Donetz-Senke und zum Vergleich der russischen borealen Oberkreide mit derjenigen Polens und Nordwesteuropas. Geologiska Föreningens i Stockholm Förhandlingar 70: 583-602.

Jeletzky, J.A., 1949. Über den taxonomischen Wert einiger morphologischer Elemente des Rostrums der belemnitellenartigen Formen (Familie Belemnitellidae Pavlow, 1913), sowie über die Gattung Belemnella (Nowak, 1913, subg.) Jeletzky, 1941, ihre Phylogenie und einige Vertreter. Neues Jahrbuch für Mineralogie, Geologie und Paläontologie B9: 257-287.

Jeletzky, J.A., 1951. The place of the Trimingham and Norwich Chalk in the Campanian-Maestrichtian succession. Geological Magazine 88: 197-208.
Jeletzky, J.A., 1958. Die jüngere Oberkreide (Oberconiac bis Maastricht) Südwestrusslands und ihr Vergleich mit der Nordwest- und Westeuropas. Beihefte zum Geologischen Jahrbuch 33: 1-157.

Johansen, B. \& Surlyk, F., 1990. Brachiopods and the stratigraphy of the upper Campanian and lower Maastrichtian Chalk of Norfolk, England. Palaeontology 33: 823-872.

Kaever, M. \& Lommerzheim, A., 1991. Die Bohrung Metelen 1001. Stratigraphie, Palökologie und Fazies zyklischer Sedimente des Campans im nordwestlichen Münsterland (NW-Deutschland). Facies 24: 267-284.

Kennedy, W.J., 1986. The Campanian-Maastrichtian ammonite sequence in the environs of Maastricht (Limburg, the Netherlands), Limburg and Liège provinces (Belgium). Newsletters on Stratigraphy 16: 149-168.

Kennedy, W.J., 1987. The ammonite fauna of the type Maastrichtian with a revision of Ammonites colligatus Binkhorst, 1861. Bulletin de l'Institut royal des Sciences naturelles de Belgique, Sciences de la Terre 56 (for 1986): 151-267.

Keutgen, N., 1997. Belemnella (Belemnella) cf. praearkhangelskii Naidin, 1964 from the Vijlen Member at Altembroeck (NE Belgium, Early Maastrichtian). Geologie en Mijnbouw 75: 341-347.

Keutgen, N. \& Jagt, J.W.M., 1999. Late Campanian belemnite faunas from LiègeLimburg (NE Belgium, SE Netherlands). Geological Survey of Belgium, Professional Paper 1998/2 (287): 1-31.

Keutgen, N., Jagt, J.W.M., Felder, P.J. \& Jagt-Yazykova, E.A., 2010. Stratigraphy of the upper Vijlen Member (Gulpen Formation; Maastrichtian) in northeast Belgium, the southeast Netherlands and the Aachen area (Germany), with special reference to belemnitellid cephalopods. Netherlands Journal of Geosciences 89: 109-136.

Keutgen, N. \& Van der Tuuk, L.A., 1991. Belemnites from the Lower Maastrichtian of Limburg, Aachen and Liège. Mededelingen Rijks Geologische Dienst 44 (for 1990): 1-39.

Kner, $\boldsymbol{R}$., 1848. Versteinerungen des Kreidemergels von Lemberg und seiner Umgebung. W. Haidinger's naturwissenschaftliche Abhandlungen 3: 1-42.

Kongiel, $\boldsymbol{R}$. , 1962. On belemnites from Maastrichtian, Campanian and Santonian sediments in the Middle Vistula Valley (Central Poland). Prace Muzeum Ziemi 5: 3-140.

Marsson, T., 1878. Die Foraminiferen der weissen Schreibkreide der Insel Rügen. Mittheilungen des naturwissenschaftlichen Vereins für Neu-Vorpommern und Rügen in Greifswald 10: 115-196.

Miller, J.S., 1823. Observations on the genus Actinocamax. Transactions of the Geological Society of London (2)2: 45-62.

Moberg, J.C., 1885. Cephalopoderna i Sveriges kritsystem. II. Artsbeskrifning. Sveriges Geologiska Undersökning C73: 1-65.

Naidin, D.P., 1952. Verkhnemelovye belemnity zapadnoj Ukrainy. Trudy Moskovskogo Geologo-Razvedochnogo Instituta imemi S. Ordzhinikidze 27: 1-126.

Naidin, D.P., 1964. Verkhnemelovye belemnitelly i belemnelly Russkoj platformy i nekotorykh sopredel'nykh oblastej. Byulleten' Moskovskogo Obshchestva Ispytatelej Prirody, Otdel geologicheskii 39: 85-97.

Naidin, D.P., 1975. Late Maastrichtian belemnitellids of Eurasia. In: Menner, W.W., Moskvin, M.M., Naidin, D.P., Solovyev, A.N. \& Shimansky, V.N. (eds): Evolution and change of the organic kingdom at the Mesozoic-Cainozoic boundary. Nauka (Moskva): 91-108. 
Niebuhr, B., 2003. Late Campanian and Early Maastrichtian ammonites from the white chalk of Kronsmoor (northern Germany) - taxonomy and stratigraphy. Acta Geologica Polonica 53: 257-281.

Niebuhr, B., 2004. Late Campanian nostoceratid ammonites from the Lehrte West Syncline near Hannover, northern Germany. In: Wood, C.J., Walaszczyk, I., Marcinowski, R. \& Tröger, K.-A. (eds): Gundolf Ernst Memorial Volume. Acta Geologica Polonica 54: 473-487.

Niebuhr, B., 2006. Multistratigraphische Gliederung der norddeutschen Schreibkreide (Coniac bis Maastricht), Korrelation von Aufschlüssen und Bohrungen. Zeitschrift der deutschen Gesellschaft Geowissenschaften 157: 245-262.

Nowak, J., 1913. Untersuchungen über die Cephalopoden der oberen Kreide in Polen. III. Teil. Bulletin international de l'Académie des Sciences de Cracovie, Classe des Sciences mathématiques et naturelles B1913: 335-415.

Odin, G.S., Hancock, J.M., Antonescu, E., Bonnemaison, M., Caron, M., Cobban, W.A., Dhondt, A.V., Gaspard, D., Ion, J., Jagt, J.W.M., Kennedy, W.J., Melinte, M., Néraudeau, D., Von Salis, K. \& Ward, P.D., 1996. Definition of a Global Boundary Stratotype Section and Point for the Campanian/Maastrichtian boundary. Bulletin de l'Institut royal des Sciences naturelles de Belgique, Sciences de la Terre 66 (Supplement): 111-117.

Ogg, J.G, Agterberg, F.P. \& Gradstein, F.M., 2004. The Cretaceous period. In: Gradstein, F.M., 0gg, J.G. \& Smith, A.G. (eds): A geologic time scale 2004. Cambridge University Press (Cambridge): 344-383.

Remin, Z., 2007. Analiza paleontologiczna i znaczenie stratygraficzne belemnitów górnego kampanu i dolnego mastrychtu profilu doliny środkowej Wisły. Archiwum Wydziau Geologii Uniwersytetu Warszawskiego, Warszawa (unpubl. PhD thesis): 1-163.

Robaszynski, F. \& Christensen, W.K., 1989. The upper Campanian-Lower Maastrichtian chalks of the Mons Basin, Belgium: a preliminary study of belemnites and foraminifera in the Harmignies and Ciply areas. Geologie en Mijnbouw 68: 391-408.

Robaszynski, F., Dhondt, A.V. \& Jagt, J.W.M., 2002. Cretaceous lithostratigraphic units (Belgium). In: Bultynck, P. \& Dejonghe, L. (eds): Guide to a revised lithostratigraphic scale of Belgium. Geologica Belgica 4 (2001): 121-134.

Roemer, F.A., 1840-1841. Die Versteinerungen des norddeutschen Kreidegebirges. Hahn'sche Hofbuchhandlung (Hannover): 1-145.

Roemer, F., 1852. Kreidebildungen von Texas und ihre organischen Einschlüsse. Adolph Marcus (Bonn): vi + 1-100.

Schlüter, C., 1876. Cephalopoden der oberen deutschen Kreide, Teil 2. Palaeontographica 24: 123-263.

Schulz, M.-G., 1978. Zur Litho- und Biostratigraphie des ObercampanUntermaastricht von Lägerdorf und Kronsmoor (SW-Holstein). Newsletters on Stratigraphy 7: 73-89.

Schulz, M.-G., 1979. Morphometrisch-variationsstatistische Untersuchungen zur Phylogenie der Belemniten-Gattung Belemnella im Untermaastricht NWEuropas. Geologisches Jahrbuch A47: 3-157.

Schulz, M.-G., 1982. Erster Nachweis der Belemnitengattung Belemnitella (B. pulchra n. sp.) im mittleren Untermaastricht NW-Deutschlands. Geologisches Jahrbuch A61: 279-293.

Schulz, M.-G., Ernst, G., Ernst, H., \& Schmid, F., 1984. Coniacian to Maastrichtian stage boundaries in the standard section of the Upper Cretaceous White Chalk of NW Germany (Lägerdorf-Kronsmoor-Hemmoor): definition and proposals. Bulletin of the Geological Society of Denmark 33: 203-215.
Schulz, M.-G. \& Schmid, F., 1983. Das Ober-Maastricht von Hemmoor (N-Deutschland): Faunenzonen-Gliederung und Korrelation mit dem OberMaastricht von Dänemark und Limburg. Newsletters on Stratigraphy 13: 21-39.

Skołozdrówna, Z., 1932. Znaczenie alveoli i szczeliny alveolarneij dla systematiki rodzaju Belemnitella (sic). Posiedzienia Naukowe Panstwowego Instytutu Geologicznego 33: 117.

Slimani, H., Louwye, S., Dusar, M. \& Lagrou, D., 2011. Connecting the Chalk Group of the Campine Basin to the dinoflagellate cyst biostratigraphy of the Campanian to Danian in borehole Meer (northernmost Belgium). In: Jagt, J.W.M., Jagt-Yazykova, E.A. \& Schins, W.J.H. (eds): A tribute to the late Felder brothers - pioneers of Limburg geology and prehistoric archaeology. Netherlands Journal of Geosciences 90: 129-164.

Stolley, E., 1892. Die Kreide Schleswig-Holsteins. Mitteilungen aus dem Mineralogischen Institut Kiel 1: 191-309.

Stolley, E., 1897. Über die Gliederung des norddeutschen und baltischen Senon sowie die dasselbe charakterisierenden Belemniten. Archiv für Anthropologie und Geologie Schleswig-Holsteins 2: 216-302.

Vonhof, H.B., Jagt, J.W.M., Immenhauser, A., Smit, J., van den Berg, Y., Saher, M., Keutgen, N. \& Reijmer, J.J.G., 2011. Belemnite-based strontium, carbon and oxygen isotope stratigraphy of the Maastrichtian stratotype area. In: Jagt, J.W.M., Jagt-Yazykova, E.A. \& Schins, W.J.H. (eds): A tribute to the late Felder brothers - pioneers of Limburg geology and prehistoric archaeology. Netherlands Journal of Geosciences 90: 259-270.

Von Schlotheim, E.F., 1813. Beiträge zur Naturgeschichte der Versteinerungen in geognostischer Hinsicht. In: Leonhard, C.C. (ed.): Leonhard's Taschenbuch für die gesamte Mineralogie mit Hinsicht auf die neuesten Entdeckungen (1)7: 1-134.

Von Schlotheim, E.F., 1820. Die Petrefakten-Kunde auf ihrem jetzigen Standpunkte durch die Beschreibung seiner Sammlung versteinerter und fossiler Überreste des Thier- und Planzenreichs der Vorwelt erläutert. Becker (Gotha): 1-437.

Walaszczyk, I., Odin, G.S. \& Dhondt, A.V., 2002. Inoceramids from the Upper Campanian and Lower Maastrichtian of the Tercis section (SW France), the Global Stratotype Section and Point for the Campanian-Maastrichtian boundary; taxonomy, biostratigraphy and correlation potential. Acta Geologica Polonica 52: 269-305.

Weiss, W., 1999. Foraminiferal biostratigraphy of the marine Maastrichtian in northern Germany. In: The Maastrichtian. A celebratory conference. Maastricht, November 17-21, 1999. The 150th anniversary of the introduction of the Maastrichtian Stage. Natuurhistorisch Museum Maastricht (Maastricht), 1 pp. 